\title{
Circulating immune complexes, serum immunoglobulins, and acute phase proteins in psoriasis and psoriatic arthritis
}

\author{
M. R. LAURENT, G. S. PANAYI, AND P. SHEPHERD* \\ From Guy's Arthritis Research Unit and the Departments of Medicine, Rheumatology, and *Chemical $\overrightarrow{\vec{\omega}}$ \\ Pathology, Guy's Hospital Medical School, London SE1 9RT
}

SUMMARY Raised levels of circulating immune complexes were found in the plasma of $47 \%$ of $\stackrel{\vec{b}}{\circ}$ patients with psoriasis and in $58 \%$ of those with psoriatic arthritis. The mean levels were significantly raised when compared with normals, but there was no difference between the 2 patient groups.

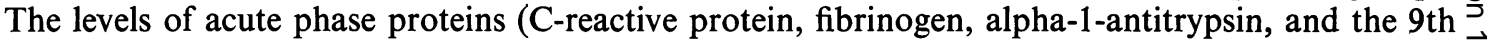
component of complement) were normal in those patients with psoriasis but were significantly 7 raised in patients with psoriatic arthritis. Serum immunoglobulin $G$ and A levels were equally $\frac{\mathbb{O}}{C}$ raised in both patient groups, immunoglobulin $\mathbf{M}$ being normal. $\mathrm{C}$-reactive protein and fibrinogen gave the best correlation with the clinical index of disease activity.

Psoriatic arthritis occurs in about $7 \%$ of patients with psoriasis, ${ }^{1}$ the reason for the development of an arthritis being unknown. In rheumatoid arthritis immune complexes have been demonstrated in serum and synovial fluid and may play a role in its pathogenesis. ${ }^{2} 3$ Immunoglobulin $G$ complexes have been found in eluates from the synovium in psoriatic arthritis, ${ }^{4}$ and it is possible that immune complexes may play a role in the pathogenesis of the arthritis.

In this study we measured circulating immune complexes using the solid phase $\mathrm{Clq}$ radioimmunoassay to determine whether they were present in patients with psoriatic arthritis but absent in those with psoriasis alone. Koskello et al. ${ }^{5}$ have shown serum caeruloplasmin levels to be normal in psoriasis but raised in severe psoriatic arthritis. Serum copper levels were raised in both groups, so it is possible that the caeruloplasmin levels were raised because it can also act as an acute phase protein. This difference between the 2 patient groups could be due to a difference in type or severity of the inflammatory response. We therefore measured C-reactive protein, fibrinogen, alpha-1-antitrypsin, and the 9th component of complement to determine whether there was a difference between the 2 patient groups with respect to these acute phase proteins.

Accepted for publication 17 March 1980

Correspondence to Dr G. S. Panayi, Department of Medicine, Guy's Hospital Medical School, London SE1 9RT.

\section{Patients and methods}

The patient groups consisted of 15 patients in hospital with severe psoriasis and 29 with psoriatic arthritis, whose skin involvement varied from mild to $\stackrel{\square}{\square}$ severe. They were compared with 21 age matched $\vec{\overrightarrow{ }}$ controls. The psoriatic arthritis patients conformed $\frac{0}{3}$ to the rheumatoid-like pattern as described by Moll and Wright $^{6}$ and were all IgM rheumatoid factor negative.

Clinical assessment of disease activity consisted of early morning stiffness measured in minutes, $\frac{5}{3}$ Ritchie index, ${ }^{7}$ and the number of active joints. An active joint was defined as one with synovial thickening, with or without an effusion. All these measurements were then scored on a 0-4 scale and then $\frac{\text { o }}{8}$ summated for each patient to give a clinical activity $D$ index. At the time of the study the psoriasis patients were receiving only topical corticosteroids and those $N$ with arthritis nonsteroidal anti-inflammatory drugs.

Serum samples were stored in aliquots at $-70^{\circ} \mathrm{C}$ and thawed only once. Purified human $\mathrm{Clq}$ was $\mathrm{E}$ prepared by the method of Reid et al. ${ }^{8}$

Immune complexes were measured by the modified $\varphi$

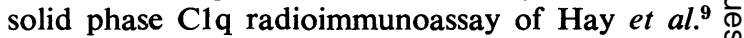
$1 \mathrm{ml}$ quantities of human $\mathrm{Clq}$ solution $(10 \mathrm{mg} / \mathrm{l}) \stackrel{\text { ? }}{?}$ in phosphate buffered saline (PBS) $\mathrm{pH} 7.4$ were $\frac{0}{0}$ incubated in polystyrene tubes (LP3, Luckham, Ltd, $\stackrel{0}{\mathbb{D}}$ Sussex) for 72 hours at $4^{\circ} \mathrm{C}$. The tubes were then $\stackrel{?}{\square}$ washed 3 times with PBS. $50 \mu$ l of test serum were $\stackrel{\square}{\circ}$ 
added to $100 \mu \mathrm{l}$ of $0.2 \mathrm{M}$ EDTA (adjusted to $\mathrm{pH}$ $7 \cdot 5$ with $\mathrm{NaOH}$ ) and incubated for 30 minutes at $37^{\circ} \mathrm{C}$. The mixture was then transferred to an ice bath. $^{2}$ Duplicate $50 \mu \mathrm{l}$ samples were placed in the coated plastic tubes together with $950 \mu l$ of PBS containing $0.05 \%$ Tween 20 (PBS-Tween). Coated tubes containing $1 \mathrm{ml}$ PBS-Tween were used as background controls. The tubes were incubated for 1 hour at $37^{\circ} \mathrm{C}$ and for 30 minutes at $4^{\circ} \mathrm{C}$. Unbound proteins were then removed by washing 3 times with cold PBS. Immune complexes bound to the C1qcoated tubes were detected by incubating the tubes with $1 \mu \mathrm{g}$ of purified radiolabelled anti-IgG in $1 \mathrm{ml}$ PBS-Tween at $37^{\circ} \mathrm{C}$ for 1 hour and then at $4^{\circ} \mathrm{C}$ for 30 minutes. Unbound labelled reagent was removed by 3 washes with cold PBS. The tubes were then counted in a gamma-ray spectrometer, the amount of radioactivity bound being a measure of the immune complexes in the patient's serum.

The acute phase proteins, $\mathrm{C}$-reactive protein, fibrinogen, 9th component of complement, alpha1-antitrypsin, and the immunoglobulins $G, A$, and $\mathbf{M}$ were measured by single radial immunodiffusion in agar, with monospecific antisera (Behring). ${ }^{10}$

Statistical evaluation was by Student's $t$ test and multiple regression analysis.

\section{Results}

Levels of circulating immune complexes were greater than the normal mean plus 2 standard deviations in $47 \%$ of patients with psoriasis and in $58 \%$ of those with psoriatic arthritis (Fig. 1). There was no significant difference between the mean levels of the 2 patient groups (psoriasis mean $\pm \mathrm{SD}, 2.6 \pm 1.9 \mathrm{mg} / 1$ serum anti-IgG bound; psoriatic arthritis, $3 \cdot 0 \pm 2 \cdot 3$ ) but when compared with the normal controls (mean $\pm \mathrm{SD}, 1 \cdot 1 \pm 0 \cdot 7$ ) the values for both patient groups were significantly raised $(\mathrm{P}<0 \cdot 01)$. There was no correlation between circulating immune complex levels and serum immunoglobulin $\mathbf{G}$ or $\mathbf{C}$-reactive protein. The level of immune complexes in patients with arthritis did not show any correlation with the clinical index of disease activity, age of onset, or disease duration.
Table 1 shows the mean acute phase protein levels. Those patients with psoriasis alone had levels that were not significantly different from normals, whereas those with psoriatic arthritis had significantly raised levels of erythrocyte sedimentation rate (ESR), C-reactive protein, fibrinogen, 9th component of complement $(P<0.01)$, and alpha1 -antitrypsin $(P<0.05)$. The patients with arthritis had raised levels of ESR, C-reactive protein, and 9th component of complement $(\mathrm{P}<0.05)$ when compared with those with psoriasis alone.

The acute phase proteins were compared with the clinical index of disease activity in those patients with psoriatic arthritis, and the resultsareshown in Table 2. C-reactive protein and fibrinogen correlated significantly with clinical disease activity $(P<0 \cdot 01)$, ESR

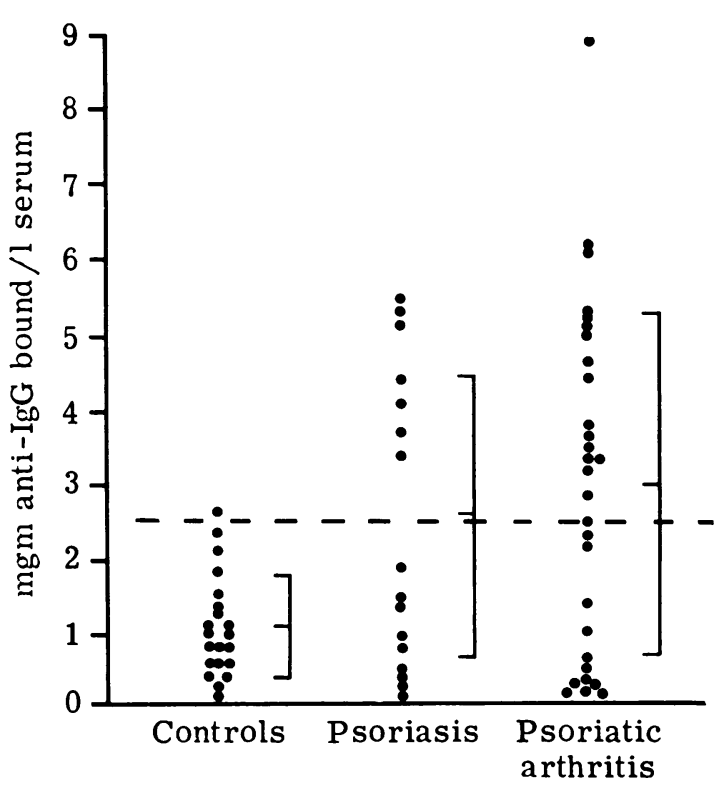

Fig. 1 Solid phase Clq binding in patients with psoriasis alone and psoriatic arthritis compared with normal controls. The vertical bars indicate mean \pm standard deviation, and the dotted horizontal line is the upper limit of normal (95\% confidence limit).

Table 1 Acute phase protein levels in normal controls and patients with psoriasis and psoriatic arthritis

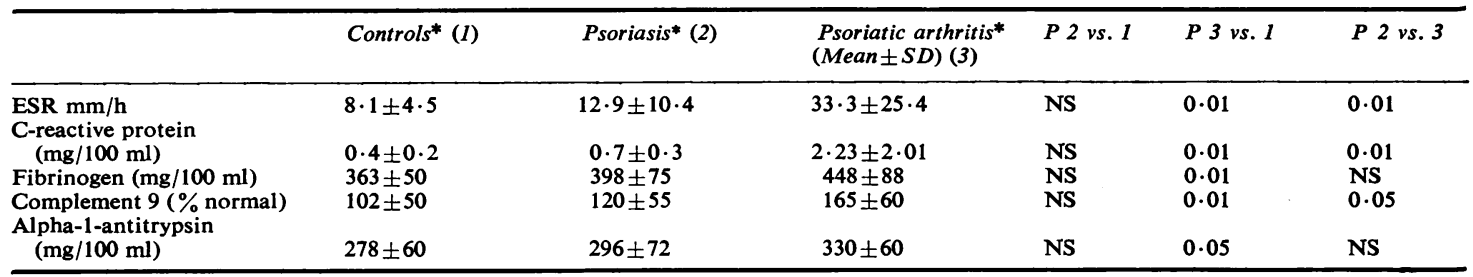

*Mean \pm standard deviation. $\mathrm{NS}=$ Not significant. (SI conversion: $\mathrm{g} / \mathrm{l}=\mathrm{mg} / 100 \mathrm{ml} \times 0.01$.) 
Table 2 Correlation between clinical assessment of disease activity, acute phase proteins, and serum immunoglobulins

\begin{tabular}{lll}
\hline $\begin{array}{l}\text { Clinical disease activity } \\
\text { Correlated with: }\end{array}$ & C-reactive protein & $\mathbf{P}=0.01$ \\
& Fibrinogen & $\mathbf{P}=0.01$ \\
& ESR & $\mathbf{P}=0.05$ \\
Complement 9 & $\mathbf{P}=0.05$ \\
Did not correlate with: & Alpha-1-antitrypsin & \\
& Immunoglobulins G, A, $\mathbf{M}$ \\
\hline
\end{tabular}

Table 3 Serum immunoglobulin levels in normal controls and patients with psoriasis and psoriatic arthritis.

\begin{tabular}{|c|c|c|c|c|c|c|}
\hline & $\begin{array}{l}\text { Controls* } \\
\text { (1) }\end{array}$ & $\begin{array}{l}\text { Psoriasis* } \\
\text { (2) }\end{array}$ & $\begin{array}{l}\text { Psoriatic } \\
\text { arthritis* } \\
\text { (3) }\end{array}$ & $\begin{array}{l}P 2 \\
\text { vs. } 1\end{array}$ & $\begin{array}{l}P 3 \\
\text { vs. } 1\end{array}$ & $\begin{array}{l}P 2 \\
\text { vs. } 3\end{array}$ \\
\hline $\begin{array}{l}\text { IgG } \\
(\mathrm{IU} / \mathrm{ml}) \\
\operatorname{IgA}\end{array}$ & $116 \pm 24$ & $158 \pm 56$ & $171 \pm 65$ & 0.01 & 0.001 & NS \\
\hline $\operatorname{IgM}^{(\mathrm{IU} / \mathrm{ml})}$ & $125 \pm 58$ & $221 \pm 76$ & $245 \pm 91$ & 0.01 & 0.001 & NS \\
\hline$(\mathrm{IU} / \mathrm{ml})$ & $113 \pm 58$ & $107 \pm 63$ & $120 \pm 67$ & NS & NS & NS \\
\hline
\end{tabular}

*Mean \pm standard deviation. NS $=$ : Not significant.

and 9th component of complement were marginally significant $(P<0.05)$, and the alpha-1-antitrypsin and immunoglobulin $\mathrm{G}, \mathrm{A}$, and $\mathrm{M}$ levels did not correlate with clinical activity.

In Table 3 mean immunoglobulin levels for IgG, $A$ and $M$ are shown. IgG and IgA levels were significantly raised for both groups (psoriasis $\mathbf{P}<$ 0.01 ; psoriatic arthritis $P<0.001$ ). Although the mean levels present in the psoriatic arthritis group were higher than those with psoriasis alone, they did not reach statistical significance. IgM levels were normal for both groups. The ratio of $\operatorname{IgA}$ to $\operatorname{IgG}$ was measured to determine their relative increases, our normal ratio being $1 \cdot 08 \pm 0 \cdot 18$ (mean $\pm \mathrm{SD}$ ). Patients with psoriasis had a ratio of $1.40 \pm 0.32$ (mean $\pm \mathrm{SD}$ ) and psoriatic arthritis $1.43 \pm 0.28$ (mean $\pm \mathrm{SD}$ ), these ratios being significantly raised in comparison with the normals $(\mathrm{P}<0.01)$ and also with those of rheumatoid arthritis patients $(1 \cdot 06 \pm$ $0 \cdot 5$, mean $\pm \mathrm{SD}, \mathrm{P}<0 \cdot 01$ ) (Highton, personal communication).

\section{Discussion}

Circulating immune complex (CIC) levels, as measured by the $\mathrm{Clq}$ solid phase radioimmunoassay, were equally raised in both psoriasis and psoriatic arthritis. In the patients with psoriasis immune complex levels did not correlate with clinical measurements of disease activity. Karsh et al.,"11 using the Clq deviation test, found raised levels of CIC in both patient groups. There was no difference between the 2 groups or correlation with disease activity. They were unable to detect $\mathrm{CIC}$ using a modified Raji cell assay measuring only IgG complexes and concluded that the complexes measured probably contained IgM rather than IgG. The method we used measures IgG complexes, and the reason for the discrepancy may be due to the assay used. It is often difficult to interpret immune complex results, because the type of complex detected varies depending on the method used. Braun-Falco et al.,12 using the C1q deviation test in psoriasis found $\mathrm{CIC}$ in $70 \%$ of patients. Therefore raised levels of CIC are present in psoriasis and psoriatic arthritis and do not appear to be specific for psoriasis.

The role of circulating immune complexes in psoriasis and psoriatic arthritis is unknown, but it is an interesting possibility that it could be related to the abnormal blood vessel morphology in this disease. Nail fold capillaries in patients with psoriatic arthritis have been shown to be meandering with tight terminal convolutions, ${ }^{13}$ an abnormality also present in psoriatic skin capillaries. ${ }^{14}$ Histologically a large number of endothelial gaps in the walls of postcapillary venules of both involved and uninvolved skin have been demonstrated. ${ }^{15}$ It is therefore possible that circulating immune complexes couldo pass through these gaps in the vessel walls and become deposited in the skin, thus initiating the pathological process. These blood vessel defects have not been demonstrated in psoriatic synovium, but Lawrence ${ }^{16}$ has postulated that, if present, they could contribute to the arthritis. The complexes we measured had IgG as the antibody, but in view of the high IgA levels it would be interesting to see whether IgA-containing complexes were present and to determine their relationship to the arthritis.

The acute phase protein levels were significantly raised only in those with arthritis. Even in the patients with severe psoriasis alone these levels were not significantly elevated. These differences could be due to 2 factors. First, they may reflect the severe inflammation present in the arthritis group; or, secondly, the arthritis is a different inflammatory process, producing the appropriate stimuli for the acute phase protein response. The ESR has been shown to be raised in psoriatic arthritis and to correlate with clinical disease activity. ${ }^{17}$ In this study C-reactive protein and fibrinogen gave a better correlation with disease activity than the ESR.

The raised levels of immunoglobulin $A$ and $\mathbf{G}$ are in agreement with previous reports. ${ }^{18} 19$ The mean levels were slightly higher in those patients with arthritis but did not correlate with disease activity. It is interesting that the ratio of $\operatorname{IgA}$ to $\mathbf{I g G}$ in psoriasis and psoriatic arthritis is higher than that in rheumatoid arthritis, showing relatively greater 
increase in IgA production. There is evidence for defective function of a $T$ cell subset, ${ }^{20}{ }^{21}$ and it has been postulated that this could be a suppressor cell which, when absent, allows increased production of $\operatorname{IgA}$. Another possibility is that the causative antigen for psoriasis may enter through the gastrointestinal tract. However, the exact reason for this disproportionate elevation of $\operatorname{IgA}$ levels is unknown.

Financial support was provided by Guy's Arthritis Research Unit and the Arthritis and Rheumatism Council.

\section{References}

1 Leczinsky C G. The incidence of arthropathy in a ten year series of psoriasis cases. Acta Derm Venereol (Stockh) 1948; 28 : 483-91.

2 Zubler R H, Nydegger U, Perrin L H, et al. Circulating and intraarticular immune complexes in patients with rheumatoid arthritis. Correlation of ${ }^{125} \mathrm{I}-\mathrm{C} 1 \mathrm{q}$ binding activity with clinical and biological features of the disease. J Clin Invest 1976; 57: 1308-19.

3 Luthra H S, McDuffie F C, Hunter G G. Immune complexes in sera and synovial fluids of patients with rheumatoid arthritis: radioimmunoassay with monoclonal rheumatoid factor. J Clin Invest 1975; 56: 458-66.

4 Munthe E. Relationship between IgG complexes and anti-IgG antibodies in rheumatoid arthritis. Acta Rheumatol Scand 1970; 16: 240-56.

5 Koskello P., Kekli M, Virkanen M, Lussus A, Somer T. Serum caeruoloplasmin concentrations in rheumatoid arthritis, ankylosing spondylitis, psoriasis and sarcoidosis. Acta Rheumatol Scand 1966; 12: 261-6.

6 Moll J M H, Wright V. Familial occurrence of psoriatic arthritis. Ann Rheum Dis 1973; 22: 181-201.

7 Ritchie D M, Doule J A, McInnes J M, et al. Clinical studies with an articular index for the assessment of joint tenderness in patients with rheumatoid arthritis. $Q J$ Med 1968; 37: 393-406.
8 Reid K B M, Lowe D M, Porter R R. Isolation and characterisation of $\mathrm{Clq}$, a subcomponent of the first component of complement. from human and rabbit sera. Biochem J 1972; 130: 749-63.

9 Hay F C, Nineham L J, Roitt I M. Routine assay for the delection of immune complexes of known immunoglobulin class using solid phase C1q. Clin Exp Immunol 1976; 24: 396-400.

10 Mancini G, Carbonara H O, Heremans J F. Immunological quantification of antigens by single radial immunodiffusion. Immunochemistry 1965; 2 : 235-54.

11 Karsh J, Espinoza L R, Dorval G, Vasey F, Wilkinson R, Osterland C K. Immune complexes in psoriasis with and without arthritis. J Rheumatol 1978; 5: 314-9.

12 Braun-Falco O, Mannel C, Sherer R. Demonstration of circulating immune complexes of psoriatic patients using ${ }^{125}$ I-Clq deviation test. Hautarzt 1977; 28: 658-60.

13 Redisch W, Messina E J, Hughes G, McEwan C. Capillarioscopic observations in rheumatic diseases. Ann Rheum Dis 1970; 29: 244-53.

14 Ross J B. The psoriatic capillary, its nature and value in the identification of the unaffected psoriatic patient. Br J Dermatol 1964; 78: 511-8.

15 Braverman I M, Yen A. Microcirculation in psoriatic skin. J Invest Dermatol 1974; 62: 493-502.

16 Lawrence J S. Discussion following paper by Thompson M, Holst G. Microcirculatory studies of the skin in the investigation of seronegative polyarthritis. 6th European Congress of Rheumatology. Lisbon, 1967; 29-39.

17 Lodin A, Gentele H, Lagerholm B, Karltorp N. Psoriatic arthritis and elevated ESR. Acta Derm Venereol (Stockh) 1957; 37: 459-64.

18 Danielson L. Immuno-electrophoretic analysis of serum proteins in psoriasis and psoriatic arthritis. Acta Rheumatol Scand 1965; 11: 112-8.

19 Guilhou T J, Clot J, Meynadier J, Lapinski H. Immunological aspects of psoriasis: Immunoglobulins and anti IgG factors. Br J Dermatol 1978; 94: 501-7.

20 Guilhou J J, Meynadier J, Clot J, Charmasson E, Dardenne M, Brachier J. Immunological aspects of psoriasis. II. Dissociated impairment of thymus-dependent lymphocytes. Br J Dermatol 1976; 95: 295-301.

21 Glinski W, Shawomir S, Langner A, Jablonsky S, Haftek M. Defective function of $T$ lymphocytes in psoriasis. J Invest Dermatol 1978; 70: 105-110. 